\title{
Window Lighting sebagai Pembentuk Dimensi dan Karakter Objek Model dalam Fotografi Potret hitam putih
}

\author{
${ }^{1}$ Yosa Fiandra| ${ }^{2}$ Yayat Sudaryat \\ Sekolah Tinggi Teknologi Bandung | Telkom University, Bandung \\ yosafiandra@gmail.com | yayatsudaryat@telkomuniversity.ac.id
}

\begin{abstract}
ABSTRAK
Artikel ini memaparkan peran window lighting dalam membentuk dimensi dan karakter objek model, terutama pada fotografi potret hitam putih. Metode yag digunakan dalam penelitian ini adalah analisis deskriptif dengan pendekatan data kualitatif. Data dikumpulkan dari observasi lapangan dan praktik secara langsung, dengan beberapa objek model sebagai sample dari penelitian. Studi literatur juga digunakan untuk mendukung dan menguatkan data yang ada. Data yang dianalsisis diverifikasi dengan unsur perwujudan karya rupa yakni unsur tangible aesthetic. Hasil penelitian ini menunjukan bahwa window lighting dapat membentuk dimensi dan karakter objek model potret hitam putih dengan menegaskan elemen visual pada objek berupa bentuk, struktur dan raut yang ada pada objek model sebagai bentuk nyata yang terindera oleh mata. Kontribusi yang dapat diberikan pada penelitian ini adalah untuk memperluas pengetahuan mengenai dasar pencahayaan pada fotografi.
\end{abstract}

Kata Kunci : Cahaya, Jendela, Fotografi, Potret, Orang,

\section{ABSTRACT}

This article describes the role of window lighting in shaping the dimensions and character of object models, especially in black and white portrait photography. The method used in this study is descriptive analysis with a qualitative data approach. Data was collected from field observations and practices directly, with several model objects as samples from the study. Literature studies are also used to support and strengthen existing data. Analyzed data is verified with elements of embodiment of the form of the tangible aesthetic element. The results of this study indicate that window lighting can form the dimensions and character of objects in the black and white portrait model by emphasizing the visual elements in the object in the form, structure and expression that exist in the object model as a tangible form perceived by the eye. The contribution that can be given to this research is to broaden the knowledge of the basic lighting in photography.

Key words : Light, Windows, Photography, Potrait, Human,

\section{PENDAHULUAN}

Sejarah fotografi berawal pada abad ke 5 sebelum masehi, dimana seorang pria asal cina bernama Mo Ti, berhasil menemukan suatu gejala alam yang sangat menarik, dimana dia mengamati pada suatu dinding didalam ruangan yang gelap terdapat suatu lubang kecil (Pinhole), dimana bagian dalam ruangan itu ada refleksi pemandangan dari luar secara terbalik melalui lubang yang dia amati tadi, ini merupakan suatu bentuk dari kamera Obscura,
Berabad-abad kemudian banyak yang menyadari dan mengagumi fenomeni ini. (Soedjono 1997:2).

Fotografi merupakan suatu kata yang berasal dari Bahasa Yunani, apalah diterjemahkan "Fos" ang mengartikan tentang Cahaya dan "Grafo" yang mengartikan tentang Lukisan atau Tulisan, Apabila kita defenisikan fotografi berarti Adalah Proses untuk menghasilkan gambar atau foto dari suatu objek, yang merekam pantulan cahaya yang 
mengenai objek tersebut pada media yang peka cahaya.

Fotografi adalah seni melihat, foto juga merupakan suatu bentuk penyampaian pesan visual ke dalam bentuk gambar, dengan foto kita bisa melihat realitas yang ada disekitar kita, secara konkrit dan akurat.

Cahaya tentu sangat dibutuhkan dalam kehidupan manusia. Hampir semua aktivitas kegiatan manusia dilakukan menggunakan cahaya, Tanpa cahaya, kehidupan di bumi ini mungkin tidak akan berjalan. Jendela merupakan bagian penting dari sebuh rumah atau bangunan, selain sebagai untuk mendapatkan cahaya dari luar rumah, untuk sirkulasi udara, jendela juga berfungsi sebagai media penghubung untuk melihat pemadangan ke luar rumah. Jendela menyediakan cahaya alami dari sinar matahari pada pagi dan siang hari.

Pencahayaan dari jendela merupakan suatu bentuk pencahayaan yang bersifat alami, hal ini dipengaruhi oleh, lokasi jendela, jumlah jendela, ukuran dan bentuk dari jendela itu sendiri. Selain dari bentuk desain jendela, pencahayaan yang maksimal juga ditentukan oleh pemilihan warna di dalam ruangan itu sendiri, sehingga dapat memantulkan dan mendistribusikan cahaya secara merata dari luar ruangan ke dalam ruangan.

Fotografi Potret merupakan salah satu genre fotografi yang berkembang dari semenjak awal ditemukannya fotografi itu sendiri. Fotografi Potret atau dalam Bahasa inggris dikenal dengan "Potrait Photography" merupakan suatu bentuk representasi objek dari orang atau model yang di foto, yang menonjolkan kepribadian dari objek model itu sendiri.

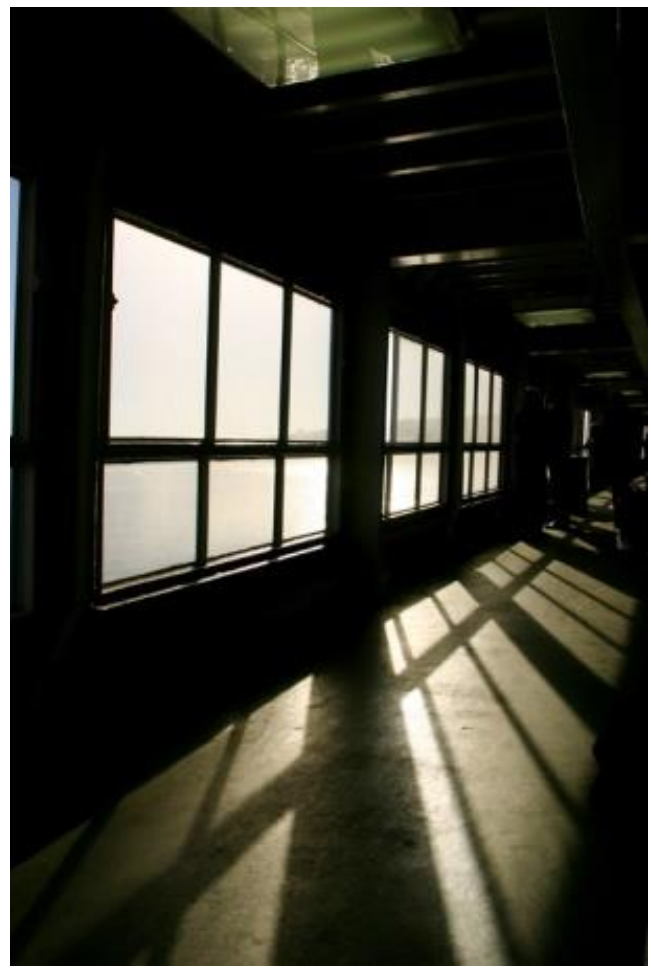

Gambar 1. Cahaya Jendela

(Sumber

:http//www.capndesign.com/photo/images/december04/fe rry-windows.jp)

Dalam dunia Fotografi cahaya adalah hal yang paling penting, tanpa cahaya, tentu tidak akan ada foto yang tercipta.

\section{METODE}

Penelitian ini menggunakan metode analisis deskriptif dengan data kualitatif. Data yang dianalisis berupa hasil potret hitam putih model manusia sebanyak dua orang. Data tersebut dipaparkan berdasarkan elemen pembentuk visualnya dengan unsur tangible aesthetic, yakni bentuk, struktur dan raut

Dalam penelitian ini peneliti menggunakan penelitian kualitatif dimana untuk memahami konsep window lighting dalam fotografi peneliti memanfaatkan landasan teori sebagai pemandu agar fokus penelitian sesuai dengan fakta di lapangan. 
Windows Light adalah teknik memotret dengan memanfaaatkan cahaya yang berasal dari jendela, Tehnik ini merupakan salah satu bentuk pelajaran dasar dari Basic fotografi tentang cahaya yang memanfaatkan pantulan cahaya matahari yang masuk ke dalam ruangan melalui jendela, biasan cahaya yang masuk bisa menghasilkan suatu bentuk cahaya yang bagus dan menghasilkan fotografi potret yang menarik. Secara teori ada dua macam sumber cahaya yang berpengaruh didalam ruangan yaitu, Pertama Sumber cahaya Alami, yang berasal dari alam, seperti cahaya matahari, bulan dan bulan, Kedua sumber cahaya buatan, seperti cahaya dari lampu, cahaya dari lilin, lampu obor, dan berbagai sumber cahaya buatan lainnya.

(S.P.Honggowidjaja,Pengaruh Signifikan Tata Cahaya Pada Desain Interior)

\section{FOTOGRAFI POTRET}

Fotografi Potret adalah salah satu genre fotografi yang berkembang dari saat awal penemuan fotografi hingga sampai sekarang. Fotografi pada awalnya dimanfaatkan manusia sebagai bentuk untuk menampilkan bentuk wujud dirinya yang sebelumnya disampaikan dalam media lukisan. Ketertarikan terhadap penemuan fotografi ini terutama disebabkan oleh hasil gambar yang dihasilkan memiliki bentuk yang nyata dibandingkan dengan lukisan. Hal ini menyebabkan popularitas fotografi potret berkembang sangat pesat semenjak ditemukannya fotografi pada awal abad ke Sembilan belas, apalagi ada kecederungan manusia yang senang jika dirinya diabadikan dalam bentuk potret fotografi. (London dan Upton, 1981:328)
Kathleen Francis menyebutkan bahwa terdapat beberapa hal penting dalam sebuah foto potret, yaitu.

1. Penonjolan Kepribadian (Personality) Menampilkan karakter seseorang.

2. Penggunaan Pencahayaan

Sebagai pembentuk objek dan karakter

3. Latar Belakang

Mendukung karakter dari subjek yang dipotret.

4. Pose Subjek

Menunjukan sikap dan kepribadian

\section{PEMBAHASAN}

Pemotretan dengan menggunakan sumber cahaya dari jendela atau disebut juga "Window Lighting" merupakan salah satu basic pelajaran fotografi dalam membuat sebuah foto, memanfaatkan cahaya alami matahari, yang masuk ke dalam ruangan, Salah satu bentuk foto yang sangat menarik dalam menggunakan pencahayaan natural dari jendela, adalah Fotografi Potret atau "Potrait Photography", dengan pencahayaan natural ini seorang fotografer bisa menghasilkan suatu foto yang alamiah, menarik, membentuk dimensi dan karakter dari objek model yang menjadi objek foto. 


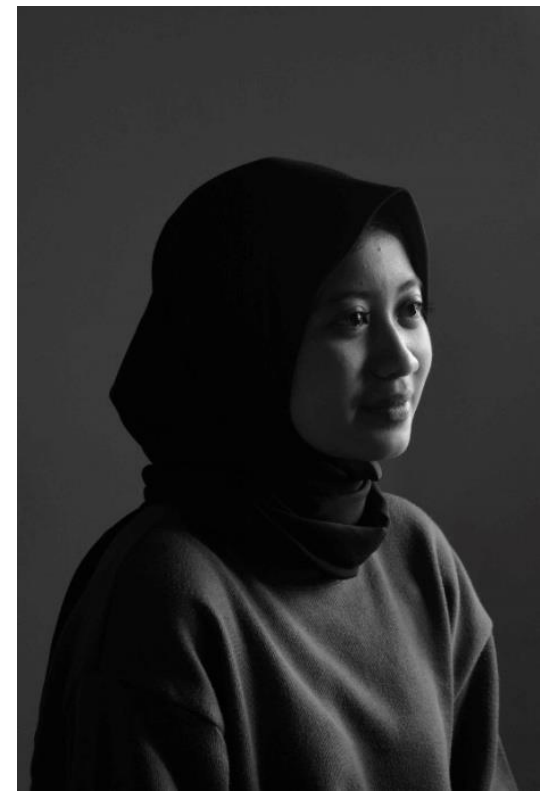

Gambar 2. Model Windows Lighting arah cahaya yang natural.

Foto : Yosa Fiandra

Foto diatas merupakan salah satu foto yang memanfaatkan sumber cahaya dari jendela, hasil foto menyerupai seperti bentuk foto distudio, kelebihan dari cahaya alami dalam windows lighting ini adalah, jendela menjadi difuser (pelembut) cahaya ke arah model, sehingga cahaya yang sampai ke model terkesan sangat lembut dan lebih alami.

\section{A. CAHAYA}

Cahaya merupakan faktor penting dalam dunia fotografi, tanpa cahaya tidak akan ada gambar atau foto yang tercipta, dalam Fotografi ada tiga sumber cahaya yaitu :

\section{A. Available Light}

Yaitu Cahaya yang alami, seperti cahaya matahari.

\section{B. Artificial Light}

Yaitu Cahaya buatan, seperti cahaya lampu, lilin, dan lain-lain

C. Mix Light

Yaitu bentuk cahaya yang menggunakan cahaya alami dan cahaya buatan, untuk menghasilkan pencahayaan gambar yang menarik

Ketiga sumber pencahayaan diatas merupakan bentuk pencahayaan yang sering dipergunakan dalam fotografi, arah cahayapun tergantung berdasarkan sudut pengambilan dari fotografer.

Ada beberapa jenis pencahayaan dalam fotografi berdasarkan sumber cahaya yang berada disekitar objek foto, Secara umum ada lima teknik dasar pencahayaan yang dipergunakan pada saat memotret yaitu :

front light, oval light, side light, rim light, back light, top light, dan ray of light.

1) Cahaya Depan (Front Light), Posisi cahaya yang jatuh didepan objek, sehingga di bagian depan objek yang akan dipenuhi oleh cahaya.

(Gambar 1)

2) Cahaya Lonjong, (Oval Light), Posisi cahaya menyinari tiga perempat bagian dari objek, sehingga terdapat sedikit bayangan pada bagian belakang dari objek.

(Gambar 2\&8)

3) Cahaya Samping, (Side Light),

Posisi cahaya yang berada pada sisi samping dari objek, jatuhnya cahaya dan bayangan terbagi menjadi dua bagian. Bagian terang dan bayangan akan berada pada posisi yang berlawanan. (Gambar $3 \& 7)$

4) Cahaya Pingir (Rim Light),

Posisi cahaya yang berada pada bagian belakang objek, dengan posisi sudut seperempat objek, objek bagian depan akan terlihat gelap dan menghasilkan garis cahaya pada pinggiran objek.

(Gambar 4\&6)

5) Cahaya Belakang, (Back Light) 
Posisi cahaya tepat pada bagian belakang objek sehingga sisi bagian depan dari objek menjadi gelap, dan tercipta garis-garis cahaya pada bagian dari belakang objek secara tegas. (Gambar 5)

Posisi Lighting Dasar
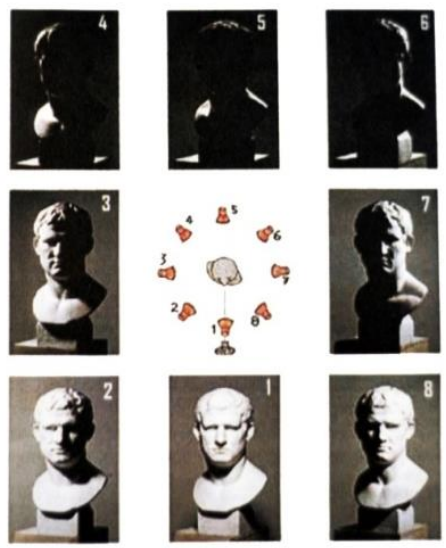

Gambar 3. Arah pencahayaan

(sumber:warna,cahaya \& Komposis; Sue Bishop)

Efek dari sinar matahari yang masuk melalui jendela merupakan salah satu bentuk dari cahaya langsung (direct light) yang menghasilkan kontras yang kuat antara bayangan dengan subjek yang terkena cahaya. Cahaya menjadi lebih menonjol dan menarik perhatian mata karena lingkungan sekitarnya mempunyai pencahayaan yang jauh lebih lemah atau gelap.

Cahaya yang masuk melalui jendela ke dalam ruangan memiliki kualitas pencahayaan langsung dan tidak langsung. Cahaya tidak langsung terjadi ketika tidak semua cahaya dapat memasuki jendela sehingga akan tercipta cahaya langsung yang sangat lembut. Dinding dalam ruangan juga ikut mempengaruhi pantulan cahaya yang masuk, dinding yang berwarna terang dapat memantulkan cahaya yang menghasilkan bayangan lembut dan cahaya tambahan yang mengisi bayangan, cahaya ini sangat baik untuk pemotretan.

\section{B. EKSPOSURE}

Eksposure artinya adalah pencahayaan, eksposure terdiri dari "Shutter Speed" yaitu kecepatan dalam menangkap cahaya, Sensivitas Cahaya "ISO", dan"Aperture" yaitu bukaan dari lensa dalam menerima cahaya. Tanpa cahaya ketiga bagian penting dari fotografi tersebut tidak dapat berjalan dengan baik.

Untuk mendapatkan hasil gambar yang menarik tentu seorang fotografer harus memahami bagaimana menggunakan eksposure dalam setiap pemotretannya, cara kerja eksposure pada intinya bagaimana menyesuaikan cahaya yang masuk, sehingga diperoleh kecerahan gambar yang maksimal, dengan mengkombinasikan kecepatan, sensivitas cahaya dan Bukaan dari lensa.

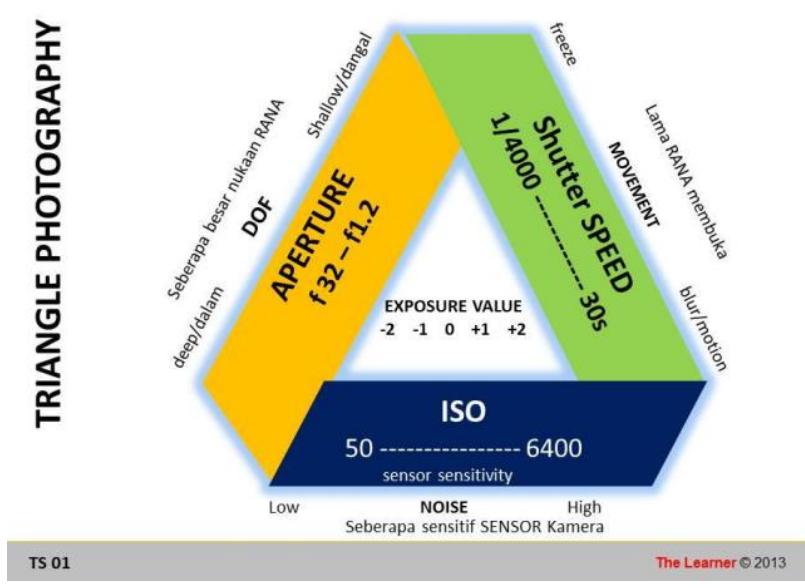

Gambar 5 ; Segitiga Eksposure

(Sumber The Learner 2013)

Untuk pemotretan dengan memanfaatkan cahaya dari jendela ini, Intensitas cahaya dalam ruangan relatif lebih lemah sehingga dalam proses pemotretan, kecepatan yang dipergunakan adalah kecepatan lambat, untuk bukaan lensa atau diagframa disarankan menggunakan bukaan besar, dan untuk sensivitas cahaya (ISO) dipergunakan adalah berkisar diantara angka 400-1000, 
tergantung pada arah cahaya dan pantulan dalam ruangan. Selain itu juga disarankan untuk menggunakan tripod supaya gambar tidak menjadi blur, karena menggunakan kecepatan rendah.

\section{SUDUT PENGAMBILAN}

Dalam membuat suatu potret fotografi, sudut pengambilan gambar ditentukan dari bagaimana seorang fotografer memanfaatkan arah cahaya yang masuk dan menyinari model yang menjadi objek fotonya.

Sudut pengambilan yang paling mudah dalam fotografi potret adalah mengambil dari posisi depan subjek. Kamera sejajar dengan mata model. Sudut pemotretan ini disebut dengan eye level, secara umum sudut pengambilan ini dapat menghasilkan gambar yang baik terutama untuk fotografi Potret. Konsep foto dengan menggunakan sudut eye level ini memberikan kesan kesetaraan, sehingga orang yang melihat foto seolah-olah berada pada posisi yang sama.

\section{ANALISIS}

Fotografi potret merupakan suatu bentuk tehnik basic fotografi yang memanfaatkan arah cahaya yang masuk ke dalam ruangan. Ada beberapa faktor yang harus menjadi perhatian bagi seorang fotografer sebelum membuat foto dengan memanfaatkan cahaya dari windows lighting, yaitu menentukan arah cahaya yang mengarah ke objek model.

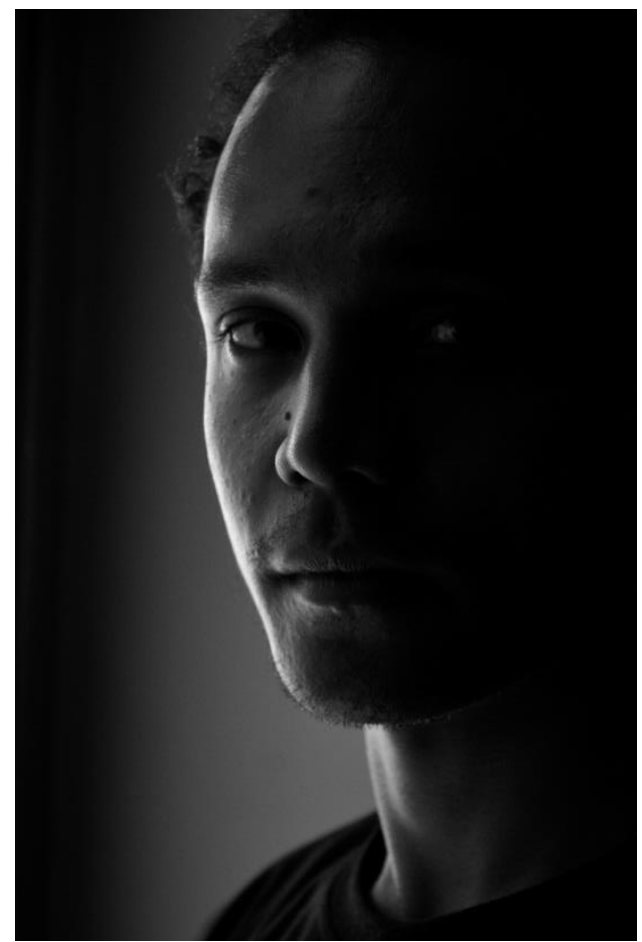

Gambar 6 : Foto model dengan windows lighting

(Foto : Yosa Fiandra)

Apabila kita buat sebuah tabel dalam membuat sebuah foto windows lighting

1. Arah cahaya berasal dari samping kiri objek Sehingga membentuk side light disisi wajah objek

2. Arah objek model menghadap ke kamera, sehingga ada interaksi antara fotografer dan model

3. Sudut pengambilan eye level,atau sejajar dengan objek model

4. Tehnis pemotretan secara manual yaitu menggunakan

F 5, speed 1/50, iso 500, white balance auto, Focal lenght $75 \mathrm{~mm}$.

5. Posisi pemotretan indoor. 


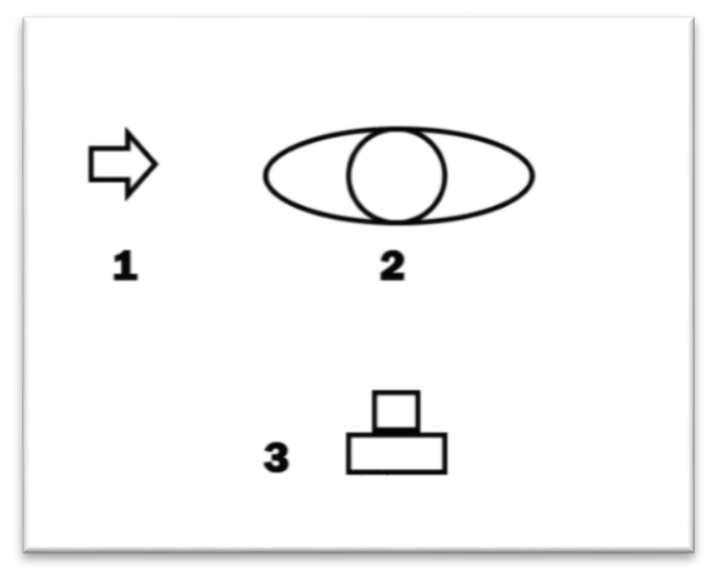

Gambar 6 : Skema Pemotretan windows lighting

(Sumber : Yosa Fiandra)

Dari skema posisi diatas dapat dilihat arah cahaya yang masuk dari samping, ditandai dengan angka 1 , objek model 2, dan posisi fotografer nomor 3. Ini merupakan salah bentuk posisi yang sangat sederhana dan paling mudah, dalam membuat suatu foto potret.

Beberapa hal yang menarik dari fotografi potret ini adalah dapat menonjolkan kepribadian dari seseorang, yang bersifat unik. Karakter personal seseorang merupakan hal yang selalu menarik karena setiap individu manusia memiliki kepribadian dan karakter yang menarik. Cahaya merupakan hal mutlak dalam fotografi potret karena menghasilkan karakteristik visual sehingga objek terlihat sangat menarik.

\section{KESIMPULAN}

Fotografi Potret atau "Potrait Photography" merupakan salah satu genre fotografi yang terus berkembang dari saat awal penemuan fotografi hingga sekarang, sebagai media baru pada saat ditemukan pada abad ke Sembilan belas. Fotografi merupakan salah satu sarana untuk mendokumentasikan diri sendiri maupun orang banyak, selain karena menarik, hal ini juga karena setiap individu manusia, sangat senang apabila diabadikan dalam bentuk foto potret, selain bisa mempresentasikan dirinya sendiri juga menampilkan karakter dan status dari individu itu sendiri.

Dalam membuat sebuah foto potret kita bisa memanfaatkan arah cahaya dari matahari yang masuk ke rumah melalui jendela, selain sebagai sumber cahaya dalam pemotretan, windows lighting juga bersifat natural. Kelebihan dari memanfaatkan cahaya dari jendela ini dalam fotografi ini yaitu selain sederhana, murah dan sangat mudah dipelajari.

\section{DAFTAR PUSTAKA}

Buku

[1] Nyoman Khunta Ratna, S.U, 2010, Metodologi Penelitian, Kajian Budaya dan Ilmu Sosial Humaniora Pada Umumnya, Yogyakarta, Pustaka Pelajar.

[2] Sri Sadono, 2012, Tehnik Dasar Fotografi Digital Fotomaster, Jakarta, Ranakata.

[3] Irwandi \& M.Fajar Apriyanto, 2012, Membaca Fotografi Potret, Jogjakarta, Gama Media

[4] Bate, Dave, 2009, Photography: The Key

Concept, New York, Berg

[5] Heret Frasthio, 2003, Kombinasi Dwi Cahaya, Jakarta, Fotomedia.

\section{Artikel Jurnal}

[1] S.P.Honggowidjaja. 2014. Pengaruh Signifikan

Tata Cahaya Pada Desain Interior. (on line).

Diakses pada 24 februari 2019 dari

http://puslit.petra.ac.id/journals/interior/

Referensi Web

[1] Isnin "Elemen pencahayaan dalam fotografi"

Diakses pada 27 februari 2019 dari

http://izinkumenulis.blogspot.com/search/label/Foto grafi. 
[2] Hariyanto, S.Pd, "Metoda Penelitian Kualitatif"

Diakses pada 2 Maret 2019 dari

https://belajarpsikologi.com/metode-penelitian-

kualitatif/ 